\title{
Efficacy of psychoeducation in bipolar patients: systematic review of randomized trials
}

\author{
Tarciso Aparecido Batista, Cristiane Von Werne Baes and Mario Francisco Juruena \\ Universidade de São Paulo, Ribeirão Preto, SP, Brazil
}

\begin{abstract}
Bipolar disorder is a recurrent and chronic disorder with significant morbidity and mortality. Currently, pharmacological treatment is considered indispensable in bipolar disorder. However, despite advances in this area, treatment remains suboptimal. A large body of research has shown that innumerable psychosocial factors influence the emergence of mood disorders. Therefore, in addition to pharmacological strategies, psychological interventions are increasingly recognized as an essential component in the treatment of bipolar patients. Among the various approaches of psychosocial interventions, psychoeducation (PE) has been one of the most used. Thus, the aim of this review was to evaluate the efficacy of PE in the clinical course, treatment adherence, and psychosocial functioning of bipolar patients by collecting data from controlled trials that used solely PE as a psychosocial approach. A systematic review of the literature was performed in the PubMed and SCOPUS databases, without date limits, using the following keywords: Psychoeducation and Bipolar disorder. We found 13 randomized controlled trials. Psychoeducation significantly improved the clinical course, treatment adherence, and psychosocial functioning of bipolar patients. It also reduced the number of relapses and recurrences per patient and increased the time to depressive, manic, hypomanic, and mixed recurrences. The number and length of hospitalizations per patient were also lower in patients who received PE. Although we found a limited number of randomized controlled trials that evaluated the efficacy of PE in bipolar disorder, the studies showed positive results in reducing relapse rates and improving long-term treatment adherence. Additionally, PE intervention improves the knowledge of the illness for both patients and caregivers to reduce their distress and improve overall social functioning. Keywords: psychoeducation, clinical course, treatment adherence, psychosocial functioning, bipolar disorder.
\end{abstract}

Received 30 October 2011; received in revised form 5 December 2011; accepted 6 October 2011. Available online 29 December 2011

\section{Introduction}

Bipolar disorder is a recurrent and chronic disorder with significant morbidity and mortality. It is characterized by a long-term episodic cyclical course of extreme fluctuations in mood that manifest as repeated manic, depressed, or mixed episodes with complete inter-episode recovery but high rates of chronicity that impact social and occupational development (Angst \& Sellaro, 2000). According to the Systematic Treatment Enhancement Program for Bipolar Disorder, 5\% of patients who fulfill the criteria for recovery suffer relapses each month (Baldassano, 2006). Although some rare individuals

Tarciso Aparecido Batista, Cristiane Von Werne Baes, Research Fellow, Post-Graduate in Mental Health, Department of Neuroscience and Behaviour, Faculty of Medicine Ribeirao Preto, University of Sao Paulo. Mario Francisco Juruena, Professor, Doctor in Psychiatry, Head, Stress and Affective Disorders Programme (SAD Programme), Department of Neurosciences and Behaviour, Faculty of Medicine Ribeirao Preto, University of Sao Paulo. Correspondence regarding this article should be directed to: Mario F Juruena, Saúde Mental-USP, Av. Tenente Catão Roxo, 2650, Monte Alegre-Campus Universitário, Ribeirão Preto, SP 14051-140, Brazil. E-mail: juruena@fmrp.usp.br may experience only a single episode of mania and depression in their lifetime, $>95 \%$ of people with bipolar disorder have recurrent episodes of mania and depression throughout their lives (Goodwin \& Jamison, 1990).

Bipolar disorder is a common disorder that affects $1 \%$ of the population. This prevalence may increase according to the diagnostic criteria used in each study (Judd \& Akiskal, 2003). Recent studies have employed broader diagnostic criteria to adequately recognize bipolar spectrum disorders in the general population. When less severe forms of the disorder are considered, the reported prevalence is $6 \%$ (Judd \& Akiskal, 2003). It is still an underdiagnosed disease among clinicians and health professionals, with a high prevalence of misdiagnosis and diagnostic shifts from other psychiatric disorders to bipolar disorder. For this reason, a large percentage of this population remains untreated (Salvatore, Tohen, Khalsa, Baethge, Tondo \& Baldessarini, 2007). High rates of misdiagnosis and lack of recognition often lead patients with bipolar disorder to have a chronic illness course with high disability, unemployment rates, and mortality (Leboyer \& Kupfer, 2010).

Bipolar patients present problems in dimensions related to quality of life such as functional impairment, 
difficulties both obtaining and maintaining employment, and interpersonal problems (Dean, Gerner \& Gerner, 2004). The World Health Organization estimates that bipolar disorder is the fifth leading cause of disability among young adults (Murray \& Lopez, 1997). According to Judd et al. (2008), patients with bipolar disorder experienced some degree of disability during the majority of long-term follow-up (54-59\% of months), including 19$23 \%$ of months with moderate and $7-9 \%$ of months with severe overall impairment. Severe disability occurs in a substantial proportion of time only in the specific area of work/employment (Judd et al., 2008). Additionally, these patients have significant increases in lifetime health service utilization, the need for disability benefits, and risk of suicidal behavior (Judd \& Akiskal, 2003). Suicidal ideation is common in bipolar disorder type I and mainly type II (Juruena et al., 2009). Twenty-five to 50\% of patients with bipolar disorder attempt suicide at least once in their lifetime; $10-19 \%$ die as a result of suicide (Chen \& Dilsaver, 1996; Jamison, 2000). Comorbid psychiatric conditions may also play an important role in increasing the risk for suicidal ideation and attempts, which may complicate the course of the illness and lead to poorer outcomes (Simon et al., 2007). A large array of comorbid psychiatric conditions is associated with bipolar disorder (Vieta et al., 2001; Treuer \& Tohen, 2010). Up to 65\% of all patients with bipolar disorder have experienced at least one other psychiatric disorder, $42 \%$ have experienced two or more comorbidities, and $24 \%$ have experienced three or more in their lifetimes. Anxiety and substance use disorders were the most common comorbid lifetime disorders (McElroy et al., 2001). Thus, given the human and financial costs associated with this disorder and burden for patients and their families, bipolar disorder is considered a major public health problem (Dunner, 2003).

Currently, pharmacological treatment is considered indispensable in bipolar disorder. However, despite advances in this area with the development of new medications with fewer side effects and greater effectiveness, treatment remains suboptimal. Recent medical treatments have focused on effective symptom relief, but these have not sufficiently reduced the burden of the disease or regained normal functioning (Goldberg, Harrow \& Grossman, 1995). Furthermore, even patients who receive the required medication dose remain relapse-free for a maximum of only 2-3 years (Solomon, Keitner, Miller, Shea \& Keller, 1995). Thus, data on the poor outcome of pharmacological treatment in $50 \%$ of patients with bipolar disorder have led to a growing awareness of the need for psychological approaches combined with medications (Goldberg, Harrow \& Grossman, 1995; Juruena, 2001; Calabrese et al., 2004).

Bipolar disorder likely results from an interplay among multiple genes that interact with environmental and developmental epigenetic factors. Recent years have seen increased investigations of the influence of psychosocial variables on the expression of the vulnerability and course of bipolar disorder. A large body of research has shown that innumerable psychosocial factors including those related to social, familial, psychological, and occupational function influence the emergence of mood disorders (Post, 1992, 2010; Zavaschi et al., 2002; Juruena, 2004; Post \& Leverich, 2006).

Therefore, in addition to pharmacological strategies, psychological interventions are increasingly recognized as an essential component in the treatment of bipolar patients (Colom \& Vieta, 2004; MachadoVieira, Santin \& Soares, 2004; Knapp \& Isolan, 2005; Goldner-Vukov, Moore, \& Cupina, 2007; Gomes \& Lafer, 2007). Several studies have shown that psychotherapeutic interventions as adjuncts to pharmacotherapy may be beneficial in fulfilling some of the unmet needs of long-term treatment performed only with pharmacotherapy (Miklowitz, George, Richards, Simoneau \& Suddath, 2003; Sajatovic, Davies \& Hrouda, 2004; Lam, McCrone, Wright \& Kerr, 2005; Miklowitz, 2008). Among the various psychosocial intervention approaches, psychoeducation (PE) has been one of the most used. Psychoeducation in bipolar disorder gives the patient a theoretical and practical approach to understand the disorder, recognize relapses early, and develop effective strategies for coping with the symptoms of the disease (Colom, Vieta, Martinez, Jorquera \& Gastó, 1998; Gonzalez-Pinto et al., 2004; Colom \& Lam, 2005; Rouget \& Aubry, 2007; Colom, 2011). Although most studies have shown positive results in improving symptoms and treatment adherence in bipolar patients treated with PE, most of these studies used other psychosocial approaches combined with PE. Thus, the aim of the present systematic review was to evaluate the efficacy of PE in the clinical course, treatment adherence, and psychosocial functioning of bipolar patients by collecting data from controlled trials that solely used PE as a psychosocial approach.

\section{Methods}

PubMed and SCOPUS were searched for articles published in English, without date limits, using the keywords Psychoeducation and Bipolar disorder. We later refined the search through a systematic review of the articles' abstracts, excluding articles that did not examine predictive value. Additionally, further manual research was conducted to search the articles cited in these papers. To be included in this review, the studies had to evaluate the efficacy of PE in bipolar disorder by considering at least one of the following outcome variables: clinical course (i.e., time to recurrence, relapse, symptom severity, and number and days of hospitalization), treatment adherence, and psychosocial functioning. We included in this systematic review 
only controlled clinical trials that used PE alone that assessed individuals with either type I or type II bipolar disorder or a combination of the two and/or their family or caregivers. Studies that evaluated PE combined with other psychosocial approaches were excluded from our review. A psychosocial intervention was considered to be any nonpharmacological intervention. We also excluded articles that evaluated the efficacy of PE in other psychiatric disorders or other medical conditions, articles that included children, adolescents, or the elderly with bipolar disorder, and review articles.

\section{Results}

We identified 51 articles in PubMed and 108 articles in SCOPUS, with two additional articles from the manual search, yielding a total of 161 articles. Following the application of the exclusion criteria, we selected 23 articles, and 10 of these were excluded because they were duplicate articles between the databases, yielding a total of 13 articles to be examined in this review.

\section{General findings}

We identified a total of only 13 randomized controlled trials. Although the pioneering studies on the efficacy of PE were conducted by Peet \& Harvey (1991), most of the randomized controlled trials with reliable methodology found in this review were published only in recent years. Moreover, most of these randomized controlled trials were produced by the Barcelona Bipolar Disorders Program. Of the 13 studies included in this review, seven studies evaluated the response to PE treatment in patients with both type I and type II bipolar disorder (D'Souza, Piskulic \& Sundram, 2010; Reinares et al., 2010; Colom et al., 2009a; Reinares et al., 2008; Colom et al., 2005; Reinares et al., 2004; Colom et al., 2003a). Of these seven studies that assessed patients with type I and type II bipolar disorder, in the study by Reinares et al. (2010), the sample was subdivided into two groups according to staging (Stage I: patients who had no functional or clinically relevant impairment; advanced stages: patients with functional or clinically relevant impairment). From a subanalysis of a larger study conducted by Colom et al. (2003a) with 120 type I and type II bipolar disorder outpatients in remission, we identified three other studies by the same group that examined the efficacy of PE exclusively in type I bipolar disorder patients (Colom et al., 2003b), bipolar patients with comorbid personality disorders (Colom et al., 2004), and type II bipolar disorder patients (Colom et al., 2009b). We also found three articles that did not specify the diagnostics of the bipolar patients enrolled in the studies (Perry, Tarrier, Morriss, McCarthy \& Limb, 1999; Peet \& Harvey, 1991; Van Gent \& Zwart, 1991). Eight of the 13 studies included in this review performed PE only with patients (Colom et al., 2003a, 2003b, 2004, 2005, 2009a, 2009b; Perry et al., 1999; Peet \& Harvey, 1991), four studies with only family or caregiver groups (Reinares et al., 2004, 2008, 2010; Van Gent \& Zwart, 1991), and one study that performed $\mathrm{PE}$ in a combined group that involved both patients and companions (D'Souza et al., 2010). In most studies, PE was conducted in groups. Only two studies conducted PE individually (Perry et al., 1999; Peet \& Harvey, 1991). Different study groups used varying numbers of sessions ranging between 5 and 21, with a follow-up that ranged from 6 months to 5 years. For more details about the methodology employed in the studies included in this review and their main results, see Table 1.

\section{Outcome measures}

To evaluate the efficacy of PE in the clinical course, treatment adherence, and psychosocial functioning of bipolar patients, we collected data from controlled trials that used only PE as a psychosocial approach.

\section{Clinical course}

Ten of the 13 studies assessed the efficacy of PE in the clinical course. Reasonably good evidence showed that PE is more effective than nonstructured meetings for preventing all relapses, manic relapses, and depressive relapses. A total of six randomized trials that investigated the clinical course found a decrease in relapse rate (Colom et al., 2003a, 2003b, 2004, 2009a, 2009b; D'Souza et al., 2010). Six of the 13 studies found increases in the time to recurrence (Colom et al., 2003a, 2003b, 2004, 2009a; Reinares et al., 2008; Reinares et al., 2010). In four studies, PE decreased the number of days of hospitalization, although all of these papers were published by the same group (Colom et al., 2003a, 2003b, 2004, 2009a). Two studies did not find any significant benefits in clinical course and number of days of hospitalization (Colom et al., 2009b; Reinares et al., 2010). Colom (2009a, 2009b) found decreases in the time that patients remained acutely ill after PE. In two studies the authors found decreases in hypomanic and manic episodes but not depressive episodes (Perry \& Harvey, 1991; Reinares et al., 2008). In a randomized controlled trial with five sessions, 14 families, and a 2-year follow-up, Van Gent \& Zwart (1991) did not find changes in bipolar symptoms. Alternatively, differences in the "dosage" and duration of PE between studies or, perhaps more importantly, the individual versus group context in which the interventions were delivered might have been responsible for these different results.

\section{Treatment adherence}

One of the main goals of PE is to improve treatment adherence, which is usually very poor in bipolar patients. Of the 13 studies identified in this review, nine 
Table 1. Main results of efficacy of psychoeducation in bipolar disorder

\begin{tabular}{|c|c|c|c|c|c|c|c|c|c|}
\hline \multirow[t]{2}{*}{ Reference } & \multirow{2}{*}{$\begin{array}{l}\text { Study } \\
\text { design }\end{array}$} & \multirow[t]{2}{*}{ Participants } & \multirow{2}{*}{$\begin{array}{l}\text { Subjects } \\
\text { (Control) }\end{array}$} & \multirow{2}{*}{$\begin{array}{l}\text { Diagnostic } \\
\text { subtype }\end{array}$} & \multirow[t]{2}{*}{ Sessions } & \multirow[t]{2}{*}{ Follow-up } & \multicolumn{3}{|c|}{ Outcome measures } \\
\hline & & & & & & & Clinical course & $\begin{array}{l}\text { Treatment } \\
\text { adherence }\end{array}$ & $\begin{array}{l}\text { Psychosocial } \\
\text { functioning }\end{array}$ \\
\hline \multirow[t]{2}{*}{$\begin{array}{l}\text { D'Souza } \\
\text { et al., } \\
2010\end{array}$} & \multirow[t]{2}{*}{$\mathrm{RCT}$} & \multirow[t]{2}{*}{$\begin{array}{l}\text { Family/ } \\
\text { Patient }\end{array}$} & \multirow[t]{2}{*}{$27(31)$} & \multirow[t]{2}{*}{$\begin{array}{l}\text { Bipolar I } \\
\text { and II }\end{array}$} & \multirow[t]{2}{*}{12} & \multirow[t]{2}{*}{14 months } & $\begin{array}{l}\downarrow \text { Relapse rate } \\
\uparrow \text { Time to } \\
\text { relapse }\end{array}$ & \multirow[t]{2}{*}{$\begin{array}{l}\uparrow \text { Medication } \\
\text { adherence }\end{array}$} & \multirow[t]{2}{*}{ Not reported } \\
\hline & & & & & & & $\begin{array}{l}\downarrow \text { Manic } \\
\text { symptoms }\end{array}$ & & \\
\hline $\begin{array}{l}\text { Reinares } \\
\text { et al., } \\
2010\end{array}$ & $\mathrm{RCT}$ & Family & $38(34)$ & $\begin{array}{l}\text { Bipolar } \\
\text { I and II } \\
\text { (patients } \\
\text { were } \\
\text { subdivided } \\
\text { into two } \\
\text { groups: } \\
\text { Stage I and } \\
\text { advanced } \\
\text { stages) }\end{array}$ & 12 & 15 months & $\begin{array}{l}\uparrow \text { Time to } \\
\text { recurrence } \\
\text { in patients in } \\
\text { Stage I } \\
\text { No significant } \\
\text { benefits in } \\
\text { patients in } \\
\text { advanced stages }\end{array}$ & Not reported & Not reported \\
\hline \multirow[t]{2}{*}{$\begin{array}{l}\text { Colom et } \\
\text { al., } 2009 \text { a }\end{array}$} & \multirow[t]{2}{*}{$\mathrm{RCT}$} & \multirow[t]{2}{*}{ Patient } & \multirow[t]{2}{*}{$60(60)$} & \multirow[t]{2}{*}{$\begin{array}{l}\text { Bipolar I } \\
\text { and II }\end{array}$} & \multirow[t]{2}{*}{21} & \multirow[t]{2}{*}{5 years } & $\begin{array}{l}\downarrow \text { Relapse rate } \\
\uparrow \text { Time to } \\
\text { recurrence }\end{array}$ & \multirow[t]{2}{*}{$\begin{array}{l}\text { No difference } \\
\text { in adherence } \\
\text { between } \\
\text { groups }\end{array}$} & \multirow[t]{2}{*}{ Not reported } \\
\hline & & & & & & & $\begin{array}{l}\downarrow \text { Time acutely } \\
\text { ill } \\
\downarrow \text { Number } \\
\text { of days of } \\
\text { hospitalization }\end{array}$ & & \\
\hline \multirow[t]{2}{*}{$\begin{array}{l}\text { Colom et } \\
\text { al., } 2009 \mathrm{~b}\end{array}$} & \multirow[t]{2}{*}{$\mathrm{RCT}$} & \multirow[t]{2}{*}{ Patient } & \multirow[t]{2}{*}{$12(8)$} & Bipolar II & 21 & 5 years & $\begin{array}{l}\downarrow \text { Relapse rate } \\
\downarrow \text { Time acutely } \\
\text { ill }\end{array}$ & Not reported & $\begin{array}{l}\uparrow \text { Levels } \\
\text { of work } \\
\text { functioning } \\
\text { and social } \\
\text { adjustment }\end{array}$ \\
\hline & & & & & & & $\begin{array}{l}\text { No difference } \\
\text { in the number } \\
\text { of days of } \\
\text { hospitalization } \\
\text { between groups }\end{array}$ & & \\
\hline $\begin{array}{l}\text { Reinares } \\
\text { et al., } \\
2008\end{array}$ & $\mathrm{RCT}$ & Family & $57(56)$ & $\begin{array}{l}\text { Bipolar I } \\
\text { and II }\end{array}$ & 12 & 1 year & $\begin{array}{l}\uparrow \text { Time to } \\
\text { recurrence } \\
\downarrow \text { Hypomanic } \\
\text { or manic } \\
\text { relapses but } \\
\text { not depressive } \\
\text { relapses }\end{array}$ & $\begin{array}{l}\text { No difference } \\
\text { in adherence } \\
\text { between } \\
\text { groups }\end{array}$ & Not reported \\
\hline $\begin{array}{l}\text { Colom et } \\
\text { al., } 2005\end{array}$ & $\mathrm{RCT}$ & Patient & $49(44)$ & $\begin{array}{l}\text { Bipolar I } \\
\text { and II }\end{array}$ & 21 & 2 years & Not reported & $\begin{array}{l}\uparrow \text { Mean serum } \\
\text { lithium levels } \\
\downarrow \text { Variation in } \\
\text { mean serum } \\
\text { lithium levels }\end{array}$ & Not reported \\
\hline
\end{tabular}


Table 1. Continued

\begin{tabular}{|c|c|c|c|c|c|c|c|c|c|}
\hline \multirow[t]{2}{*}{ Reference } & \multirow{2}{*}{$\begin{array}{l}\text { Study } \\
\text { design }\end{array}$} & \multirow[t]{2}{*}{ Participants } & \multirow{2}{*}{$\begin{array}{l}\text { Subjects } \\
\text { (Control) }\end{array}$} & \multirow{2}{*}{$\begin{array}{l}\text { Diagnostic } \\
\text { subtype }\end{array}$} & \multirow[t]{2}{*}{ Sessions } & \multirow[t]{2}{*}{ Follow-up } & \multicolumn{3}{|c|}{ Outcome measures } \\
\hline & & & & & & & Clinical course & $\begin{array}{l}\text { Treatment } \\
\text { adherence }\end{array}$ & $\begin{array}{l}\text { Psychosocial } \\
\text { functioning }\end{array}$ \\
\hline $\begin{array}{l}\text { Colom et } \\
\text { al., } 2004\end{array}$ & $\mathrm{RCT}$ & Patient & $15(22)$ & $\begin{array}{l}\text { Bipolar I } \\
\text { and II with } \\
\text { comorbid } \\
\text { personality } \\
\text { disorders }\end{array}$ & 21 & 2 years & $\begin{array}{l}\downarrow \text { Relapse rate } \\
\uparrow \text { Time to } \\
\text { recurrence } \\
\downarrow \text { Number } \\
\text { of days of } \\
\text { hospitalization } \\
\text { in group with } \\
\text { PE but no } \\
\text { difference in } \\
\text { number of } \\
\text { hospitalizations }\end{array}$ & Not reported & Not reported \\
\hline $\begin{array}{l}\text { Reinares } \\
\text { et al., } \\
2004\end{array}$ & $\mathrm{RCT}$ & Family & $30(15)$ & $\begin{array}{l}\text { Bipolar I } \\
\text { and II }\end{array}$ & 12 & $\begin{array}{l}\text { Unspeci- } \\
\text { fied }\end{array}$ & Not reported & Not reported & $\begin{array}{l}\uparrow \text { Caregiver } \\
\text { knowledge of } \\
\text { the illness } \\
\downarrow \text { Caregiver } \\
\text { distress } \\
\text { No } \\
\text { differences } \\
\text { in the family } \\
\text { relationship } \\
\text { between } \\
\text { groups }\end{array}$ \\
\hline $\begin{array}{l}\text { Colom et } \\
\text { al., 2003a }\end{array}$ & $\mathrm{RCT}$ & Patient & $60(60)$ & $\begin{array}{l}\text { Bipolar I } \\
\text { and II }\end{array}$ & 21 & 2 years & $\begin{array}{l}\downarrow \text { Relapse rate } \\
\uparrow \text { Time to } \\
\text { recurrence } \\
\downarrow \text { Number } \\
\text { and days of } \\
\text { hospitalizations }\end{array}$ & $\begin{array}{l}\uparrow \text { Lithium } \\
\text { levels }(p=.03) \\
\text { in PE group at } \\
\text { 2-year follow- } \\
\text { up }\end{array}$ & Not reported \\
\hline $\begin{array}{l}\text { Colom et } \\
\text { al., } 2003 \mathrm{~b}\end{array}$ & $\mathrm{RCT}$ & Patient & $25(25)$ & Bipolar I & 20 & 2 years & $\begin{array}{l}\downarrow \text { Relapse rate } \\
\uparrow \text { Time to } \\
\text { recurrence } \\
\downarrow \text { Number of } \\
\text { hospitalizations }\end{array}$ & $\begin{array}{l}\text { No } \\
\text { difference in } \\
\text { pharmacologic } \\
\text { treatment } \\
\text { between } \\
\text { groups }\end{array}$ & Not reported \\
\hline $\begin{array}{l}\text { Perry et } \\
\text { al., } 1999\end{array}$ & $\mathrm{RCT}$ & Patient & $34(35)$ & Unspecified & $7-12$ & 18 months & $\begin{array}{l}\downarrow \text { Manic } \\
\text { relapses but } \\
\text { not depressive } \\
\text { relapses }\end{array}$ & $\begin{array}{l}\text { No difference } \\
\text { in adherence } \\
\text { between } \\
\text { groups }\end{array}$ & $\begin{array}{l}\uparrow \text { Overall } \\
\text { social } \\
\text { functioning } \\
\text { and } \\
\text { employment }\end{array}$ \\
\hline
\end{tabular}


Table 1. Continued

\begin{tabular}{|c|c|c|c|c|c|c|c|c|c|}
\hline \multirow[t]{2}{*}{ Reference } & \multirow{2}{*}{$\begin{array}{l}\text { Study } \\
\text { design }\end{array}$} & \multirow[t]{2}{*}{ Participants } & \multirow{2}{*}{$\begin{array}{l}\text { Subjects } \\
\text { (Control) }\end{array}$} & \multirow{2}{*}{$\begin{array}{l}\text { Diagnostic } \\
\text { subtype }\end{array}$} & \multirow[t]{2}{*}{ Sessions } & \multirow[t]{2}{*}{ Follow-up } & \multicolumn{3}{|c|}{ Outcome measures } \\
\hline & & & & & & & Clinical course & $\begin{array}{l}\text { Treatment } \\
\text { adherence }\end{array}$ & $\begin{array}{l}\text { Psychosocial } \\
\text { functioning }\end{array}$ \\
\hline $\begin{array}{l}\text { Peet, \& } \\
\text { Harvey, } \\
1991\end{array}$ & $\mathrm{RCT}$ & Patient & $30(30)$ & Unspecified & $\begin{array}{l}\text { Not } \\
\text { reported }\end{array}$ & 6 months & Not reported & $\begin{array}{l}\uparrow \text { Patient } \\
\text { knowledge } \\
\text { about lithium }\end{array}$ & Not reported \\
\hline $\begin{array}{l}\text { Van Gent, } \\
\text { \& Zwart, } \\
1991\end{array}$ & RCT & Family & $14(12)$ & Unspecified & 5 & 2 years & $\begin{array}{l}\text { No change in } \\
\text { symptoms }\end{array}$ & $\begin{array}{l}\text { Nonadherence } \\
\text { did not differ } \\
\text { between } \\
\text { groups } \\
\text { ^ Partner } \\
\text { knowledge } \\
\text { about lithium }\end{array}$ & $\begin{array}{l}\uparrow \text { Partner } \\
\text { knowledge } \\
\text { about illness } \\
\text { and social } \\
\text { strategies }\end{array}$ \\
\hline
\end{tabular}

$\uparrow$, increase; $\downarrow$, decrease; PE, psychoeducation; RCT, randomized controlled trial.

evaluated the efficacy of PE in treatment adherence. In five of these studies, no difference in adherence was found between groups (Harvey, 1991; Van Gent \& Zwart, 1991; Colom et al., 2003a, 2003b; Reinares et al., 2008). Two of the studies demonstrated that PE increased mean lithium levels (Colom et al., 2003b, 2005). Two studies reported that patient and partner knowledge about lithium increased after PE (Harvey, 1991; Van Gent \& Zwart, 1991). D’Souza et al. (2010) found an increase in medication adherence after $12 \mathrm{PE}$ sessions.

\section{Psychosocial functioning}

Of the 13 studies identified in this review, only four evaluated improvements in psychosocial functioning with PE. Perry et al. (1999) found a significant improvement in overall social functioning and employment for 18 months in the experimental treatment group that received PE. Colom et al. (2009b) evaluated the efficacy of PE only in type II bipolar disorder patients and found higher mean levels of functioning compared with the control group. Reinares et al. (2004) and Van Gent \& Zwart (1991) also evaluated the effects of PE on functionality and quality of life in patient families and caregivers. They found that PE in caregivers may improve the caregivers' knowledge of the illness, reduce their distress, or alter their subjective burden and beliefs about the link between disruptions in their life and the patient's illness and also may improve social strategies.

\section{Discussion}

We used rigorous systematic methods to review all randomized trials of psychosocial treatments for the prevention of relapse in bipolar disorder. Most of these found a decrease in relapse rate (Colom et al., 2003a, 2003b, 2004, 2009a, 2009b; D'Souza et al., 2010). An improvement in overall social functioning could be a synthesis of these reviews regarding psychosocial functioning with PE (Harvey, 1991; Van Gent \& Zwart, 1991; Reinares et al., 2004; Colom et al., 2009b). One of the main targets of PE concerns the enhancement of treatment adherence, which is usually very poor in bipolar patients, even when euthymic. Significant improvements in overall social functioning (Harvey, 1991; Van Gent \& Zwart, 1991; Colom et al., 2003b, 2009a; Reinares et al., 2008) or increased mean lithium levels after PE (Colom et al., 2003b, 2005) were found in most of the studies in this systematic review. Another important issue is patient and family knowledge of treatments such as mood stabilizer as lithium increased adherence after PE (Harvey, 1991; Van Gent \& Zwart, 1991; D’Souza et al., 2010). However, this may be viewed negatively by some professionals in other fields of psychiatry. Nevertheless, the truth is that poor compliance often has much to do with misinformation or ignorance among relatives and the public. Nonadherence to medication is part of the reason for the failure of drugs to treat bipolar patients. However, some patients reported that they adhered consistently to prophylactic medication but still experienced relapses. The mechanism of action of PE remains unknown. We may hypothesize that teaching lifestyle regularity may play a role in the prevention of depression, whereas early detection of prodromal symptoms may be crucial for preventing mania, which has been reported in previous studies.

\section{Conclusion and final considerations}

Bipolar disorder is a complex illness. The effectiveness of any treatment program largely depends on its ability to target selective problems in specific phases of the illness. 
Psychoeducation also appears to be a key intervention in the enhancement of treatment adherence and improvement of long-term outcome in several medical conditions. Destigmatization and improvements in illness awareness play crucial roles in the beginning of bipolar PE because patients may have preconceived notions about their illness that may push them toward denial. Understanding denial and learning the biological causes of the illness constitute essential parts of the first PE sessions. Another important issue is the distinction between causes (biological) and triggering factors. This issue will be crucial for establishing good treatment adherence later in the course of the illness.

\section{References}

Angst, J., \& Sellaro, R. (2000). Historical perspectives and natural history of bipolar disorder. Biological Psychiatry, 48, 445-457.

Baldassano, C. (2006). Illness course, comorbidity, gender, and suicidality in patients with bipolar disorder. Journal of Clinical Psychiatry, 67(Suppl 11), 8-11.

Calabrese, J. R., Kasper, S., Johnson, G., Tajima, O., Vieta, E., Yatham, L. N., \& Young, A. H. (2004). International Consensus Group on Bipolar I Depression Treatment Guidelines. Journal of Clinical Psychiatry, 65(4), 571-579.

Chen, Y. W., \& Dilsaver, S. C. (1996). Lifetime rates of suicide attempts among subjects with bipolar and unipolar disorders relative to subjects with other Axis I disorders. Biological Psychiatry, 39, 896-899.

Colom, F. (2011). Keeping therapies simple: Psychoeducation in the prevention of relapse in affective disorders. British Journal of Psychiatry, 198, 338-340

Colom, F., \& Lam, D. (2005). Psychoeducation: Improving outcomes in bipolar disorder. European Psychiatry, 20, 359-364.

Colom, F., \& Vieta, E. (2004). A perspective on the use of psychoeducation, cognitive-behavioral therapy and interpersonal therapy for bipolar patients. Bipolar Disorders, 6, 480-486.

Colom, F., Vieta, E., Martinez, A., Jorquera, A., \& Gastó, C. (1998). What is the role of psychotherapy in the treatment of bipolar disorder? Psychotherapy and Psychosomatics, 67, 3-9.

Colom, F., Vieta, E., Martínez-Arán, A., Reinares, M., Goikolea, J. M., Benabarre, A., ... Corominas, J. (2003a). A randomized trial on the efficacy of group psychoeducation in the prophylaxis of recurrences in bipolar patients whose disease is in remission. Archives of General Psychiatry, 60, 402-407.

Colom, F., Vieta, E., Reinares, M., Martínez-Arán, A., Torrent, C., Goikolea, J. M., \& Gastó, C. (2003b). Psychoeducation efficacy in bipolar disorders: Beyond compliance enhancement. Journal of Clinical Psychiatry, 64, 1101-1105.

Colom, F., Vieta, E., Sánchez-Moreno, J., Goikolea, J. M., Popova, E., Bonnin, C. M., \& Scott, J. (2009a). Psychoeducation for bipolar II disorder: An exploratory, 5-year outcome subanalysis. Journal of Affective Disorders, 112, 30-35.

Colom, F., Vieta, E., Sánchez-Moreno, J., Martínez-Arán, A., Reinares, M., Goikolea, J. M., \& Scott, J. (2005). Stabilizing the stabilizer: Group psychoeducation enhances the stability of serum lithium levels. Bipolar Disorders, 7(Suppl 5), 32-36.

Colom, F., Vieta, E., Sánchez-Moreno, J., Martínez-Arán, A., Torrent, C., Reinares, M., ... Comes, M. (2004). Psychoeducation in bipolar patients with comorbid personality disorders. Bipolar Disorders, 6, 294-298.

Colom, F., Vieta, E., Sánchez-Moreno, J., Palomino-Otiniano, R., Reinares, M., Goikolea, J. M., ... Martínez-Arán, A. (2009b). Group psychoeducation for stabilised bipolar disorders: 5-Year outcome of a randomised clinical trial. British Journal of Psychiatry, 194(3), 260-265.

Dean, B. B., Gerner, D., \& Gerner, R. H. (2004). A systematic review evaluating health-related quality of life, work impairment, and healthcare costs and utilization in bipolar disorder. Current Medical Research and Opinion, 20(2), 139-154.

D’Souza, R., Piskulic, D., \& Sundram, S. (2010). A brief dyadic group based psychoeducation program improves relapse rates in recently remitted bipolar disorder: A pilot randomised controlled trial.
Journal of Affective Disorders, 120, 272-276.

Dunner, D. L. (2003). Clinical consequences of under-recognized bipolar spectrum disorder. Bipolar Disorders, 5(6), 456-463.

Goldberg, J. F., Harrow, M., \& Grossman, L. S. (1995). Course and outcome in bipolar affective disorder: A longitudinal follow-up study. American Journal of Psychiatry, 152, 379-384.

Goldner-Vukov, M., Moore, L. J., \& Cupina, D. (2007). Bipolar disorder: From psychoeducational to existential group therapy. Australasian Psychiatry, 15(1), 30-34.

Gomes, B. C., \& Lafer, B. (2007). Group psychotherapy for bipolar disorder patients. Revista de Psiquiatria Clínica, 34(2), 84-89.

Gonzalez-Pinto, A., Gonzalez, C., Enjuto, S., Fernandez de Corres, B., Lopez, P., Palomo, J., Perez de Heredia, J.L. (2004). Psychoeducation and cognitive-behavioral therapy in bipolar disorder: An update. Acta Psychiatrica Scandinavica, 109(2), 83-90.

Goodwin, F. K., \& Jamison, K. R. (1990). Manic-depressive illness. New York: Oxford University Press.

Jamison, K. R. (2000). Suicide and bipolar disorder. Journal of Clinical Psychiatry, 61(Suppl 9), 47-51.

Judd, L. L., \& Akiskal, H. S. (2003). The prevalence and disability of bipolar spectrum disorders in the US population: Re-analysis of the ECA database taking into account subthreshold cases. Journal of Affective Disorders, 73, 123-131.

Judd, L. L., Schettler, P. J., Solomon, D. A., Maser, J. D., Coryell, W., Endicott, J., \& Akiskal, H. S., (2008). Psychosocial disability and work role function compared across the long-term course of bipolar I, bipolar II and unipolar major depressive disorders. Journal of Affective Disorders, 108, 49-58.

Juruena, M. F., (2004). Transtorno afetivo bipolar: abordagem da terapia cognitiva. In W.P. Knapp (Ed.), Terapia cognitiva-comportamental na pratica psiquiatrica (pp. 317-327). Porto Alegre: ArtMed.

Juruena, M.F. (2001). Terapia cognitiva: Abordagem para o transtorno afetivo bipolar. Revista de Psiquiatria Clínica, 28(6), 322-330.

Juruena, M. F., Ottoni, G. L., Machado-Vieira, R., Carneiro, R. M., Weingarthner, N., Marquardt, A., ... Busnello, E.A. (2009). Bipolar I and II disorder residual symptoms: Oxcarbazepine and carbamazepine as add-on treatment to lithium in a double-blind, randomized trial. Progress in Neuro-Psychopharmacology \& Biological Psychiatry, 33, 94-99.

Knapp, P., \& Isolan, L. (2005). Psychotherapeutic approach in bipolar disorder. Revista de Psiquiatria Clínica, 32(Suppl 1), 98-104.

Lam, D. H., McCrone, P., Wright K., \& Kerr, N. (2005). Cost-effectiveness of relapse-prevention cognitive therapy for bipolar disorder: 30-Month study. British Journal of Psychiatry, 186, 500-506.

Leboyer, M., \& Kupfer, D. J. (2010). Bipolar disorder: New perspectives in health care and prevention. Journal of Clinical Psychiatry, 71(12), 1689-1695.

Machado-Vieira, R., Santin, A. \& Soares, J. C. (2004). The multidisciplinary team approach to the treatment of bipolar disorder: An overview. Revista Brasileira de Psiquiatria, 26(Suppl 3), 51-53.

McElroy, S. L. Altshuler, L. L., Suppes T., Keck, P. E., Jr., Frye, M. A., Denicoff, K. D., ... Post, R.M. (2001). Axis I psychiatric comorbidity and its relationship to historical illness variables in 288 patients with bipolar disorder. American Journal of Psychiatry, $158,420-426$.

Miklowitz, D. J. (2008). Adjunctive psychotherapy for bipolar disorder: State of the evidence. American Journal of Psychiatry, 165(11), 1408-1419.

Miklowitz, D. J., George, E. L., Richards, J. A., Simoneau, T. L., \& Suddath, R. L. (2003). A randomized study of familyfocused psychoeducation and pharmacotherapy in the outpatient management of bipolar disorder. Archives of General Psychiatry, 60(9), 904-912.

Murray, C. J., \& Lopez, A. D. (1997). Global mortality, disability, and the contribution of risk factors: Global Burden of Disease Study. Lancet, 349, 1436-1442.

Peet, M., \& Harvey, N. S. (1991). Lithium maintenance: 1. A standard education programme for patients. British Journal of Psychiatry, 158, 197-200

Perry, A., Tarrier, N., Morriss, R., McCarthy, E., \& Limb, K. (1999). Randomised controlled trial of efficacy of teaching patients with bipolar disorder to identify early symptoms of relapse and obtain treatment. British Medical Journal, 318, 149-153.

Post, R. M. (1992). Transduction of psychosocial stress into the neurobiology of recurrent affective disorder. American Journal of Psychiatry, 149, 999-1010. 
Post, R. M. (2010). Mechanisms of illness progression in the recurrent affective disorders. Neurotoxicity Research, 18, 256-271.

Post, R. M., \& Leverich, G. S. (2006). The role of psychosocial stress in the onset and progression of bipolar disorder and its comorbidities: The need for earlier and alternative modes of therapeutic intervention. Development and Psychopathology, 18, 1181-1211.

Reinares, M., Colom, F., Rosa, A. R., Bonnín, C. M., Franco, C., Solé, B., Kapczinski, F., \& Vieta, E. (2010). The impact of staging bipolar disorder on treatment outcome of family psychoeducation. Journal of Affective Disorders, 123, 81-86.

Reinares, M., Colom, F., Sánchez-Moreno, J., Torrent, C., MartínezArán, A., Comes, M., Vieta, E. (2008). Impact of caregiver group psychoeducation on the course and outcome of bipolar patients in remission: A randomized controlled trial. Bipolar Disorders, 10, 511-519.

Reinares, M., Vieta, E., Colom, F., Martínez-Arán, A., Torrent, C., Comes, M., ... Sanchez-Moreno, J.(2004). Impact of a psychoeducational family intervention on caregivers of stabilized bipolar patients. Psychotherapy and Psychosomatics, 73, 312-319.

Rouget, B. W., \& Aubry, J. M. (2007). Efficacy of psychoeducational approaches on bipolar disorders: A review of the literature. Journal of Affective Disorders, 98, 11-27.

Sajatovic, M., Davies, M., \& Hrouda, D. R. (2004). Enhancement of treatment adherence among patients with bipolar disorder. Psychiatric Services, 55, 264-269.

Salvatore, P., Tohen, M., Khalsa, H. M., Baethge, C., Tondo, L., \& Baldessarini, R. J. (2007). Longitudinal research on bipolar disorders. Epidemiologia e Psichiatria Sociale, 16, 109-117.

Simon, N. M., Zalta, A. K., Otto, M. W., Ostacher, M. J., Fischmann, D., Chow, C. W., ... Pollack, M. H. (2007). The association of comorbid anxiety disorders with suicide attempts and suicidal ideation in outpatients with bipolar disorder. Journal of Psychiatric Research, 41, 255-264.

Solomon, D. A., Keitner, G. I., Miller, I. W., Shea, M. T., \& Keller, M. B. (1995). Course of illness and maintenance treatments for patients with bipolar disorder. Journal of Clinical Psychiatry, 56(1), 5-13.

Treuer, T., \& Tohen, M. (2010). Predicting the course and outcome of bipolar disorder: A review. European Psychiatry, 25, 328-333.

Van Gent, E. M., \& Zwart, F. M. (1991). Psychoeducation of partners of bipolar-manic patients. Journal of Affective Disorders, 21(1), 15-18.

Vieta, E., Colom, F., Corbella, B., Martinez-Aran, A., Reinares, M., Benabarre, A., \& Gasto, C. (2001). Clinical correlates of psychiatry comorbidity in bipolar I patients. Bipolar Disorders, 3(5), 253-258.

Zavaschi, M. L. S., Satler, F., Poester, D., Vargas, C. F., Piazenski, R. Rohde, L. A. P., \& Eizirik, C. L. (2002). Associação entre trauma por perda na infância e depressão na vida adulta. Revista Brasileira de Psiquiatria, 24(4), 189-195. 